\title{
MEMPERKUAT FUNGSI DAN PERAN PENGAWASAN BADAN PERMUSYAWARATAN DESA (BPD) MELALUI ADVOKASI HAK WARGA ATAS INFORMASI PUBLIK UNTUK MEMBANGUN TATA KELOLA PEMERINTAHAN DESA
}

\author{
Rochmad Effendy \\ Dosen Program Studi Ilmu Komunikasi FISIP Universitas Merdeka Malang \\ email: rochmad.effendy@unmer.ac.id
}

\begin{abstract}
Unlike during the New Order era which saw village as an extension of the central government without adequate authority to run the village government, village now has recently become self-governing community equipped with broad authority to manage their own affairs for the sake of realizing people's welfare. It is an entity of community combined with government. It is community who possesses special governmental organizational structure with unique and vast authority to carry out development programs. In doing so, they handle themselves autonomously based on their own cultural values, their initiatives. As such, the central government has nothing but to respect and concede the uniqueness of its each respective village across the nation. In addition, central government has to allocate state budget to realize social and economic justice for more than 17,000 villages. This is the way the Village Law No 62014 has designed which differs dramatically from the previous village law. It has adopted recognition and subsidiarity principle in managing village development. In order this to materialize, Village Council whose membership consists elected representatives from among the villagers prominent figures has been empowered its political roles by means of annulling its inherent legislative authorities. To pave the way, it is positioned outside the formal village government organizational structure which makes it fit to function as representative of villagers civil organization. Given this setting, the Council's main duty is to fight to people's interest by preventing themselves from village government vested political interest. To make things better, the law has authorized it to organize a strategic villagers gathering held annually namely Village Meeting. As the key actor of the meeting, the council members has to show off their capacities in political communication as well as public communication to run village democratic governance whose operating values are transparency and accountability. For this to occur, advocating people's information rights is necessary requirement. By so doing, those values will institutionalize within village government daily operations by establishing Public Information and Archives Operator as required by Public Information Transparency Law No 112008 which will bring about good village governance.
\end{abstract}

Key Word: Information Rights: Civil Society: Public Information Transparency; Self-Governing Community: Recognition; Subsidiarity; Public Communication.

\section{PENDAHULUAN}

Dalam lintasan sejarah nasional, desa telah mengalami bentuk tindakan sewenangwenang dan ketidakadilan oleh pemerintah pusat. Sebagai lembaga sosial dengan keunikan dan keberagaman nama, norma dan struktur tatanan sosial budaya yang telah wujud secara turun temurun, desa lewat UU No 5 Tahun 1979 telah diseragamkan mengikuti nama, dan struktur pemerintah ala Jawa. Tidak hanya mengalami penyeragaman, desa juga telah dijadikan sebagai

Volume 1, Nomor 2, Oktober 2016 perpanjangan tangan pemerintahan pusat untuk selanjutnya dimanfaatkan untuk melanggengkan kekuasaan politik sentralistik Orde Baru. Seiring dengan beralihnya era reformasi yang menerapkan asas desentralisasi dan otonomi daerah, maka pengakuan terhadap eksistensi keberagaman dan keunikan desa mulai diberlalukan lewat UU No 22 Tahun 1999 yang kemudian dirubah dengan UU No 32 tahun 2004 tentang Pemerintah Daerah. Perubahan tatanan sosial ekonomi dan politik lokal desa akhirnya PUBLISIA (Jurnal Ilmu Administrasi Publik) | 51 
terjadi secara drastis setelah diterapkannya UU Desa No 6 tahun 2014. Nah salah satu prinsip penting UU ini adalah asas asas rekognisi yang mewajibkan negara mengakui dan menghormati desa sebagai self-governing community yakni masyarakat hukum yang berpemerintahan dan pemerintahan masyarakat yang memiliki kewenangan berskala lokal. Asas pengakuan dan penghormatan yang bertujuan untuk mewujudkan keadilan sosial ekonomi ini hanya bisa terlaksana kalau dibarengi dengan redistribusi ekonomi kepada desa. Tidak heran, makanya kalau desa memperoleh kucuran dana melimpah dari APBN dan APBD. Agar pengaturan pembangunan desa dapat terlaksana baik, kewenangan penuh untuk mengurus dan mengatur urusan pembangunan desa diberikan. Ini sekaligus sebagai konsekwensi dari penerapan asas subsidiaritas yang menempatkan desa sebagai entitas warga yang otonom mengurusi kepentingannya secara mandiri. Desa, makanya tidak lagi sebagai perpanjangan dari pemerintahan daerah atau pemerintah pusat. Dengan tatanan seperti ini akan dapat mewujudkan desa "catur sakti" yang bertenaga secara sosial, berdaulat secara politik, berdaya secara ekonomi, dan bermartabsecara budaya yang dikenal dengan

UU Desa memang menjadi 'berkah melimpah ruah' bagi desa. Hal ini hanya akan mewujud apabila didahului dengan penyiapan pranata sosial politik seperti istitusionalisasi kultur demokrasi yang kuat yang mampu mewujudkan tata kelola pemerintahan desa yang baik (village good governance) yakni melalui pelembagaan tata laksana yang menerapkan aspek transparasi, akuntabilitas, responsivitas, dialog dan delibrasi. Mekanisme ini diharapkan akan mampu menyelesaikan semua permasalahan desa seperti kemiskinan, buruknya sarana infrastruktur dan kualitas layanan publik serta ketimpangan sosial. Cita-cita mencapai kesejahteraan warga desa yang disandarkan pada UU Desa hanya akan tercapai kalau mereka diperdayakan dengan merevitalisasi pranata sosial (keguyuban, gotong royong) yang telah ada serta membangun kapasitas masyarakat sebagai konsekwensi dari masyarakat yang berpemerintahan mandiri (self-governing community). Perubahan regulasi desa papar Antlov (2016: 37) tidak cukup untuk mampu mewujudkan cita-cita tersebut. Ini harus dibarengi dengan pelembagaan demokrasi dan upaya pemberdayaan masyarakat. Kalau mereka tidak diberdayakan salah satunya lewat pelibatan dalam proses pengambilan keputusan publik, maka elit desa akan memanfaatkan peluang tersebut untuk kepentingan sempit politik ekonomi mereka. Antlov (2016:38) mengatakan, "decentralisation must come with democracy and empowerment - it must allow for the active and equitable involvement of people outside of formal state structures. Otherwise, when government is decentralised, the local elites simply usurp the new powers". Keadaan seperti ini rawan terhadap penyelewengan kewenangan yang berakibat pada merebaknya tindakan korupsi. Potensi tindak pidana korupsi akibat dari lemahnya pengawasan baik dari pemerintah dan masyarakat ini ditemukan Komisi Pemberantasan Korupsi (KPK) dalam laporannya yang diterbitkan tahun 2015. 
Hal tersebut lantas diperburuk dengan dikeluarkannya BPD dari unsur penyelenggara pemerintahan desa ditambah dengan dikurangi peran legislasinya. Meski demikian, peran politik BPD diperkuat pada aspek pengawasan terhadap kinerja pemerintahan desa. Di samping itu, BPD dibebani tugas sebagai penanggungjawab penyelenggaraan Musyawarah Desa yang merupakan konstitusi tertinggi desa serta forum untuk mengambil keputusan strategis desa. Lembaga yang merupakan representasi warga desa ini adalah aktor politik desa yang menjalankan komunikasi politik dengan pemerintahan desa. Komunikasi politik yang dijalankan hendaknya diarahkan untuk memperkuat demokrasi desa. Ini bisa dilakukan salah satunya adalah dengan mengadvokasi warga masyarakat tentang pentingya keterbukaan informasi publik pemerintahan desa yang juga merupakan badan publik yang diwajibkan undang untuk menerapkannya. Berdasarkan paparan di atas, artikel konseptual ini hendak mendiskusikan peran strategis BPD sebagai unsur masyarakat sipil untuk melakukan advokasi akan pentingnya implementasi keterbukaan informasi publik. Ini tidak hanya akan memperkuat fungsi pengawasan BPD tapi juga sekaligus meneguhkan posisi tawar masyarakat dalam proses politik desa sehingga terjadi check and balance dalam kehidupan demokrasi desa.

\section{PEMBAHASAN}

\section{Mengenal Desa Baru}

Berbeda dengan perundangan desa sebelumnya, UU Desa No 6/2014 telah menegaskan desa sebagai sebagai organisasi campuran (hybrid) antara masyarakat berpemerintahan (self-governing community) dengan pemerintahan lokal (local selfgovernment). Desa, sehingga desa berbentuk pemerintahan masyarakat atau pemerintahan berbasis masyarakat. Konsekwensinya, desa jelas Sutoro Eko (2014: 35) bermakna pemerintahan dan sekaligus masyarakat yang membentuk kesatuan (entitas) hukum. Desa tidak identik dengan pemerintah desa dan kepala desa. Desa mengindikasikan pemerintahan dan masyarakat yang karenanya membentuk membentuk kesatuan (entitas) hukum.Desa makanya merupakan organisasi pemerintahan yang paling kecil, paling bawah, paling depan dan paling dekat dengan masyarakat. Posisi sebagai sebagai masyarakat yang berpemerintahan (selfgoverning community) ini berdampak pada perubahan model pembangunan dari community driven development/CDD (pembangunan yang digerakkan masyarakat akibat implementasi program eksternal pemerintah pusat) menjadi pembangunan yang digerakkan desa /village driven development (VDD).

Model pembangunan VDD ini menurut Sutoro Eko (2014:45-46) dapat dijelaskan sebagai berikut. Sebagai sebuah kesatuan kolektif yang menggabungkan antara pemerintah desa dan masyarakat, maka desa memiliki kemandirian yang didukung dengan kewenangan, diskresi dan kapasitas lokal. Kepala desa, makanya bertindak bukan sebagai kepanjangan tangan pemerintah, melainkan berdiri dan bertindak sebagai pemimpin masyarakat. Tidak heran, kalau otoritas dan akuntabilitas pemerintah desa mendapatkan legitimasi dari masyarakat. 
Untuk itu, semua kepentingan dan kegiatan pemerintahan dan pembangunan diikat dan dilembagakan secara utuh dan kolektif dalam sistem desa. Desa dengan demikian memiliki pemerintahan yang kuat yang mampu menjadi penggerak potensi lokal yang mampu melindungi seluruh warga secara langsung termasuk kaum marginal dan perempuan. Pola pembangunan yang diterapkan hendaknya berbasis pada pemanfaatan aset lokal lewat pelembagaan perencanaan dan penganggaran secara inklusif dan partisipatoris. Agar proses dapat berjalan mulus, pelembagaan nilai-nilai transparansi, akuntabilitas, partisipasi, inklusivitas dan keseteraan gender menjadi keniscayaan. Hal ini akan dapat terlaksana kalau ada institusionaliasi mekanisme representasi dan deliberasi dan koalisi serta pertautan (engagement) antar segenap pemangku kepentingan di desa. Untuk itu diperlukan warga yang kritis, aktif dan terorganisir yang memiliki kesadaran politik terhadap hak dan kepentingan mereka yang selanjutnya ikut aktif berpartisipasi dalam penyelenggaraan pemerintahan dan pembangunan desa. Tatanan seperti ini diarahkan untuk mencapai keadilan sosial ekonomi yang makanya memerlukan dana Dana Alokasi Desa dari pemerintah sebagai bentuk redistribusi ekonomi dari negara. Dirancang seperti ini, desa makanya akan memiliki martabat budaya kuat untuk mengelola masyarakat dan sumberdaya lokal.

Rekognisi papar Sutoro Eko (2014: 27) berarti menghormati kesamaan status dan posisi; menghargai keberagaman atau keunikan yang diarahkan untuk mencapai keadilan sosial. Ini berarti tidak hanya memberikan pengakuan, penghormatan terhadap identitas kultural yang berbeda, tetapi harus dibarengi dengan redistribusi sosial ekonomi. Dengan demikian, rekognisi selalu bermuara pada keadilan budaya dan redistribusi ekonomi untuk menjamin keadilan ekonomi. Dengan kata lain, rekognisi berarti bukan campur tangan (intervensi), memaksa dan mematikan institusi (tatanan, organisasi, pranata, kearifan) yang telah ada, tapi bertindak memanfaatkan, mendukung dan memperkuat institusi yang sudah ada. Singkat kata, negara mengakui dan menghormati terhadap keragaman desa, kedudukan, kewenangan dan hak asal-usul maupun susunan pemerintahan. Tidak hanya itu, negara juga wajib melakukan redistribusi ekonomi dalam bentuk alokasi dana dari APBN maupun APBD. Transfer dana ini merupakan jalan keluar terhadap ketidakadilan sosial-ekonomi terhadap desa akibat intervensi, eksploitasi dan marginalisasi yang dilakukan oleh negara. Tidak hanya itu, UU Desa lanjut Sutoro Eko (2014:30) juga melakukan proteksi kultural dan politik terhadap desa dari tindakan imposisi dan mutilasi yang dilakukan oleh supradesa, politisi dan investor.

Asas subsidiaritas bertolak belakang dengan asas residualitas yang berarti kewenangan sisa setelah terbagi habis antara pemerintah pusat dengan pemerintah daerah provinsi dan kabupaten. Tidak heran, kalau implementasi asas ini yang biasanya sebagai konsekwensi dari prinsip desentralisasi telah menempatkan desa hanya sebagai perpanjangan pemerintahan di atasnya; mendudukkannya sebagai pemerintahan administratif yang menerima limpahan 
kewenangan dari pemeritahan kabupaten/kota. Pemerintah menurut Sutoro Eko (2014: 31) harus memberikan dukungan penuh dan fasilitiasi terhadap desa. Dengan kata lain, alih alih mencampuri urusan internal desa, pemerintah harus mendorong, memberikan kepercayaan dan mendukung prakarsa dan tindakan desa dalam mengatur dan mengurus kepentingan masyarakat setempat. Ini selaras dengan dengan salah satu tujuan penting UU No. 6/2014, yakni memperkuat desa sebagai subjek pembangunan, yang mampu dan mandiri mengembangkan prakarsa dan aset desa untuk kesejahteraan bersama. Perbedaan desa lama dan baru dapat dilihat dari tabel di bawah ini.

\section{Tabel 1 : Perspektif Desa Lama Vs Desa Baru}

\begin{tabular}{|c|c|c|}
\hline Hal & Desa Lama & Desa Baru \\
\hline Payung hukum & $\begin{array}{l}\text { UU Pemerintahan Daerah No. } \\
\text { 32/2004 dan PP No. 72/2005 }\end{array}$ & UU Desa No. 6/2014 \\
\hline Asas utama & Desentralisasi-residualitas & Rekognisi-subsidiaritas \\
\hline Kedudukan & $\begin{array}{l}\text { Sebagai organisasipemerintahan } \\
\text { yang berada dalam sistem } \\
\text { pemerintahan kabupaten kota (local } \\
\text { state government) }\end{array}$ & $\begin{array}{l}\text { Sebagai pemerintahan } \\
\text { masyarakat, hybrid antara self- } \\
\text { governing community dan local } \\
\text { self government. }\end{array}$ \\
\hline Posisi dan peran & Kabupaten/Kota mempunyai & Kabupaten/Kota mempunyai \\
\hline kabupaten/kota & $\begin{array}{l}\text { kewenangan besar dan luas dalam } \\
\text { mengatur dan mengurus desa }\end{array}$ & $\begin{array}{l}\text { kewenangan terbatas dan strategis } \\
\text { dalam mengatur dan mengurus desa; } \\
\text { termasuk mengatur dan mengurus } \\
\text { bidang urusan desa yang tidak perlu } \\
\text { ditangani langsung oleh pusat }\end{array}$ \\
\hline $\begin{array}{l}\text { Delivery } \\
\text { kewenangan dan } \\
\text { program }\end{array}$ & Target & Mandat \\
\hline Politik Tempat & $\begin{array}{l}\text { Desa : Sebagai lokasi proyek dari } \\
\text { atas }\end{array}$ & $\begin{array}{l}\text { Arena : Desa sebagai arena bagi orang } \\
\text { desa untuk menyelenggarakan } \\
\text { pemerintahan, pembangunan, } \\
\text { pemberdayaan dan kemasyarakatan }\end{array}$ \\
\hline $\begin{array}{l}\text { Posisi dalam } \\
\text { pembangunan }\end{array}$ & Objek & Subjek \\
\hline $\begin{array}{l}\text { Model } \\
\text { Pembangunan }\end{array}$ & $\begin{array}{l}\text { Government driven development atau } \\
\text { community driven development }\end{array}$ & Village driven development \\
\hline $\begin{array}{l}\text { Pendekatan dan } \\
\text { tindakan }\end{array}$ & Imposisi dan mutilasi & Fasilitasi, emansipasi dan konsolidasi \\
\hline
\end{tabular}

Berkaitan dengan kehidupan radikal dan komunitarian. Ketiganya demokrasi desa, UU No. 6/2014 merancang mendambakan penerapan prinsip demokrasi campuran antara tradisiliberal, akuntabilitas sebagai tujuan utama. 
Akuntabilitas pemimpin tidak hanya diukur dari integritasnya yang bersih dari korupsi, tetapi juga juga ditentukan oleh karakter lain seperti inovatif, visioner, proaktif, progresif danberkinerja baik.Implementasi prinsip menjadi keniscayaan saat ditemukan fakta bahwa kehidupan demokrasi desa justru bermuara pada ketimpangan sosial ekonomi di kalangan wara masyarakat. Untuk itu, mekanisme pengawasan ketat demi keberingambangan politik / check and balances mutlak diterapkan. BPD menjadi aktor strategis yang bertanggungjawab untuk melaksanakan hal ini. Di samping itu, BPD harus mampu melembagakan nilai-nilai kebebasan, transparansi, akuntabilitas dan partisipasi. Agar hal dapat berjalan, dimensi tata kelola organisasi warga sipil dan partisipasi perlu menjadi perhatian utama. Ini sekaligus menjadi solusi untuk memperkuat hak-hak warga, citizenship dan kedaulatan rakyat. Organisasi dan partisipasi warga ini tidak cukup hanya diwadahi sebagai invited participation lewat lembaga kemasyarakatan, tapi mereka harus didorong untuk mengorganisir diri mereka secara mandiri sebagai popular participation. UU No.6/2014 tidak mengatur secara eksplisit organisasi warga itu, tetapi pada prinsipnya sesuai Pasal 68, warga masyarakat mempunyai hak untuk berpartisipasi, yang tentu bisa menggunakan organisasi mandiri sebagai wadah partisipasi. Yang terakhir adalah bahwa pemikiran kaum komunitarian sangat cocok dengan konteks sosiokultural masyarakat desa. Asas kebersamaan, kegotongroyongan, kekeluargaan dan musyawarah dalam UU
No. 6/2014 mencerminkan pemikiran kaum komunitarian (Sutoro Eko.et.al. 2014; 157).

\section{Perkembangan Posisi BPD Era Orde Baru- Reformasi}

BPD merupakan lembaga perwakilan desa yang menjalankan fungsi pengawasan, legislasi dan penganggaran. Dengan setting politik seperti ini, parlemen desa ini akan mampu menciptakan mekanisme check and balance dalam percaturan politik yang selanjuntnya akan menyehatkan demokrasi desa. Sejarah perkembangan, BPD telah mengalami beberapa kali perubahan peran, fungsi dan kedudukan. Mulai dari hanya sekedar lembaga pelengkap 'pemanis' demokrasi akibat kedudukannya dibawah kendali kepala desa. Lembaga yang disebut sebagai Lembaga Musyarawah Desa ini ditegaskan dalam UU No 5 /1979. Perubahan signifikan kemudian terjadi dalam UU No 22/1922. Nama lembaga pun berubah dari lembaga permusyawaratan menjadi perwakilan dengan kedudukan politik yang strategis sebagai penyelenggara pemerintahan desa sehingga posisinya setara dengan kepala desa. Peran dan fungsinya juga diperluas yang tidak hanya peran perwakilan tapi juga meliputi legislasi, pengawasan, dan penganggaran. Namun, peran dan fungsi ini seperti tercatat dalam UU No 32/2004 kemudian diperlemah dengan membatasinya sebatas pada legislasi dan perwakilan. Ini terjadi meski kedudukannya sejajar dengan kepala desa sebagai penyelenggara pemerintahan desa. Peran, fungsi dan posisinya semakin dipersempit pada UU No 6/2014. Di sini fungsi legislasi PBD dibatasi. 
Sekarang ia berada di luar struktur penyelenggara pemerintahan desa. Ini dapat dilihat dari pengertian BPD menurut Undang Nomor 6 Tahun 2014) tentang Desa yang menyatakan Badan Permusyawaratan Desa atau yang disebut dengan nama lain adalah lembaga yang melaksanakan fungsi pemerintahan yang anggotanya merupakan wakil dari penduduk Desa berdasarkan keterwakilan wilayah dan ditetapkan secara demokratis. Hal ini kemudian dipertegaskan dalam Pasal 26 pasal 1 yang menyatakan Kepala Desa bertugas menyelenggarakan Pemerintahan Desa, melaksanakan Pembangunan Desa, pembinaan kemasyarakatan Desa, dan pemberdayaan masyarakat Desa. Ini bertolak belakang dengan ketentuan UU No 32/2014 yang dipertegas dalam Pasal 1 angka 8 Peraturan Pemerintah Nomor 72 Tahun 2005 tentang Desa, bahwa Badan Permusyawaratan Desa atau yang disebut dengan nama lain, selanjutnya disingkat BPD, adalah lembaga yang merupakan perwujudan demokrasi dalam penyelenggaraan pemerintahan desa sebagai unsur penyelenggara pemerintahan desa. Berkaitan dengan sejarah perkembangan BPD dari tahun 1979 hingga 2014 dapat dilihat pada tabel 2. Sementara perbandingan konten antara UU No 32/2004 dan UU No 6/2014 dilihat dari sisi kedudukan, fungsi politik dan hukum digambarkan pada tabel berikut.

Tabel 2: Perkembangan Badan Permusyawaratan Desa dari 1979-2014

\begin{tabular}{|c|c|c|c|c|}
\hline Indikator & UU No 5/1979 & UU No 22/1999 & UU No $32 / 2004$ & UU No 6/2014 \\
\hline \multirow[t]{3}{*}{ Istilah } & Lembaga & Badan & Badan & Badan \\
\hline & Musyawarah & Perwakilan Desa & Permusyawaratan & Permusyawaratan \\
\hline & Desa & & Desa & Desa \\
\hline \multirow[t]{9}{*}{ Kedudukan } & Sebagai & Sebagai & Sebagai & Bukan sebagai \\
\hline & pemerintah desa, & penyelenggara & penyelenggara & unsur \\
\hline & berada dibawah & pemerintahan & pemerintahan & penyelenggara \\
\hline & Kepala Desa. & desa, sejajar & desa, sejajar & pemerintahan \\
\hline & & dengan Kepala & dengan Kepala & desa, tidak sejajar \\
\hline & & Desa. & Desa & dengan Kepala \\
\hline & & & & Desa, berada di \\
\hline & & & & luar struktur \\
\hline & & & & $\begin{array}{l}\text { pemerintahan } \\
\text { desa }\end{array}$ \\
\hline \multirow{4}{*}{ Fungsi } & Musyawarah & Legislasi - & Legislasi - & Legislasi \\
\hline & & Pengawasan & Perwakilan & (terbatas) \\
\hline & & Perwakilan- & & Perwakilan \\
\hline & & Anggaran & & Pengawasan \\
\hline \multirow{3}{*}{$\begin{array}{l}\text { Penegasan } \\
\text { dalam satu } \\
\text { pasal UU/PP }\end{array}$} & Belum, masih & Tidak ada, masih & Sudah ditegaskan, & Tidak ada, masih \\
\hline & $\begin{array}{l}\text { melalui } \\
\text { penafsiran }\end{array}$ & $\begin{array}{l}\text { melaluı } \\
\text { penafsiran dalam }\end{array}$ & & $\begin{array}{l}\text { melaluı } \\
\text { penafsiran dalam }\end{array}$ \\
\hline & $\begin{array}{l}\text { dalam pasal } \\
\text { tertentu. }\end{array}$ & pasal tertentu. & & pasal tertentu \\
\hline Calon & Kepala Dusun & Berasal dari & Merupakan & Bebas asalkan \\
\hline
\end{tabular}

Volume 2, Nomor 1, April 2017 PUBLISIA (Jurnal Ilmu Administrasi Publik) | 57 


\begin{tabular}{|c|c|c|c|c|}
\hline anggota & $\begin{array}{l}\text { - Pimpinan } \\
\text { lembaga } \\
\text { kemasyarakatan } \\
\text { - Pemuka } \\
\text { masyawarakat }\end{array}$ & $\begin{array}{l}\text { kalangan } \\
\text { tertentu, yang } \\
\text { memenuhi syarat } \\
\text { - adat - agama - } \\
\text { organisasi sosial } \\
\text { politik - golongan } \\
\text { profesi - unsur } \\
\text { pemuka } \\
\text { masyarakat }\end{array}$ & $\begin{array}{l}\text { keterwakilan } \\
\text { golongan tertentu, } \\
\text { seperti: - Ketua RW } \\
\text { - Pemangku adat - } \\
\text { Golongan profesi - } \\
\text { Pemuka agama - } \\
\text { Tokoh atau } \\
\text { pemuka } \\
\text { masyarakat lain }\end{array}$ & $\begin{array}{l}\text { memenuhi syarat, } \\
\text { didasarkan pada } \\
\text { keterwakilan } \\
\text { wilayah }\end{array}$ \\
\hline $\begin{array}{l}\text { Pemilihan } \\
\text { anggota }\end{array}$ & $\begin{array}{l}\text { Musyawarah } \\
\text { KaDes dan } \\
\text { Sekdes (ex } \\
\text { oficio) menjadi } \\
\text { ketua dan wakil }\end{array}$ & $\begin{array}{l}\text { Pemilihan } \\
\text { langsung }\end{array}$ & $\begin{array}{l}\text { Musyawarah dan } \\
\text { mufakat }\end{array}$ & $\begin{array}{l}\text { Pemilihan } \\
\text { langsung atau } \\
\text { musyawarah }\end{array}$ \\
\hline
\end{tabular}

Sumber: Ardhiwinda Kusumaputra, Ngesti Dwi Prasetyo (tanpa tahun: 14-13)

Pengertian tersebut memberikan pemahaman bahwa BPD bukan merupakan unsur penyelenggara pemerintahan desa. Lembaga ini memang memiliki fungsi pemerintahan, tapi ia berdiri sendiri di luar struktur pemerintahan desa.Berada di luar struktur pemerintahan desa menurut Ardhiwinda (tanpa tahun: 17) membuat fungsi dan peran BPD kurang optimal yang pada gilirannya akan mengurangi legitimasinya dalam penyelenggaraan fungsi tersebut. Meski demikian BPD tetap memiliki peran strategis melaksanakan fungsi pemerintahan, terutama dalam menjalankan peran komunikasi politik dan komunikasi publiknya. UU Desa, makanya membekalinya dengan "panggung" politik berupa forum Musyawarah Desa untuk mengoptimalkan peran strategis tersebut. Sebagai aktor utama forum strategis yang dihadiri oleh Pemerintah Desa, dan unsur masyarakat untuk menyepakati hal yang bersifat strategisdalam penyelenggaraan Pemerintahan Desa ini, BPD dituntut untuk cakap dan piawai dalam mengelola forum untuk memainkan dua peran sekaligus yakni komunikasi politik dan komunikasi publik. Forum Musyawarah Desa ini menurut Sutoro Eko (2014: 165) dapat disebut sebagai perluasan dari peran politik BPD (extended $\mathrm{BPD})$.

Kedudukan baru BPD ini berpotensi menurut Sutoro Eko (2014: 165) mengakibatkan beberapa kemungkinan plus minus hubungan antara kepala desa, BPD dan masyarakat. Pertama, fungsi politik BPD yang menguat akan memperkuat kontrol dan legitimasi kekuasaan kepala desa. Pada saat yang sama musyawarah desa akan menciptakan kebersamaan antara pemerintah desa, BPD, lembaga kemasyarakatan dan unsur-unsur masyarakat untuk membangun dan melaksanakan visi-misi perubahan desa.Ini dapat bermuara pada terhindarinya konflik langsung antara kepala desa dan BPD. Kedua, memiliki kekuatan legal dalam menyelenggarakan pemerintahan seperti menetapkan APB Desa dan Peraturan Desa, kepala desa yang mempunyai hasrat menyelewengkan kekuasaan bisa saja 
mengabaikan kesepakatan yang dibangun dalam pembahasan bersama antara kepala desa dan BPD maupun kesepakatan dalam musyawarah desa.

Tindakan ini dibenarkan secara legal tetapi tidak legitimate secara politik. Kalau ini terjadi, di sinilah diperlukan kecakapan politik BPD untuk menyelesaikan permasalahan tersebut. Berkaitan dengan relasi kedua pihak tersebut, Sutoro Eko (2014: 167) memaparkan ada empat jenis hubungan yakni dominatif, kolutif, konfliktual, dan kemitraan. Dari keempat relasi tersebut, hubungan kemitraan menjadi alternatf pilihan terbaik. Lewat relasi ini akan tercipta kebijakan desa yang demokratis dan berpihak warga, jika dilakukan secara terbuka. Tapi relasi ini akan berubah menjadi persekongkolan kolutif ketika dilakukan secara tertutup dan tidak ada diskusi yang kritis.

\section{Tabel 3 : Kedudukan dan fungsi BPD menurut UU 32/2004 dan UU 6/2014}

\begin{tabular}{|c|c|c|c|}
\hline No & Komponen & UU No. 32/2004 & UU No. 6/2014 \\
\hline 1 & Definisi & $\begin{array}{l}\text { Lembaga yang merupa } \\
\text { kan perwujudan demokrasi } \\
\text { dalam penyelenggaraan } \\
\text { pemerintahan desa } \\
\text { sebagai unsur penyelenggara } \\
\text { pemerintahan desa }\end{array}$ & $\begin{array}{l}\text { Lembaga yang melaksanakan } \\
\text { fungsi pemerintahan yang } \\
\text { anggotanya merupakan wakil } \\
\text { dari penduduk Desa } \\
\text { berdasarkan keterwakilan } \\
\text { wilayah dan ditetapkan secara } \\
\text { demokratis }\end{array}$ \\
\hline 2 & Kedudukan BPD & $\begin{array}{l}\text { Sebagai unsur penyelenggara } \\
\text { pemerintahan desa. BPD } \\
\text { berwenang dan ikut mengatur } \\
\text { dan mengurus desa }\end{array}$ & $\begin{array}{l}\text { Sebagai lembaga desa yang } \\
\text { terlibat melaksanakan fungsi } \\
\text { pemerintahan, tetapi tidak } \\
\text { secara penuh ikut mengatur } \\
\text { dan mengurus desa. }\end{array}$ \\
\hline 3 & Fungsi hukum & $\begin{array}{l}\text { Fungsi hukum/legislasi kuat: } \\
\text { Menetapkan peraturan desa } \\
\text { bersama Kepala Desa }\end{array}$ & $\begin{array}{l}\text { Fungsi hukum/legislasi lemah: } \\
\text { Membahas dan menyepakati } \\
\text { Rancangan Peraturan Desa } \\
\text { bersama Kepala Desa, }\end{array}$ \\
\hline 4 & Fungsi politik & $\begin{array}{l}\text { BPD sebagai kanal } \\
\text { (penyambung) aspirasi } \\
\text { masyarakat dan melakukan } \\
\text { Pengawasan terhadap } \\
\text { Pelaksanaan Peraturan Desa } \\
\text { (Perdes) dan Peraturan } \\
\text { Kepala Desa }\end{array}$ & $\begin{array}{l}\text { Menampung dan menyalurkan } \\
\text { aspirasi masyarakat Desa; } \\
\text { Melakukan pengawasan } \\
\text { kinerja Kepala Desa } \\
\text { Menyelenggarakan } \\
\text { musyawarah } \\
\text { desa }\end{array}$ \\
\hline
\end{tabular}

Sumber : Eko Sutoro, 2015; 189

BPD sebagai Kekuatan Masyarakat Sipil Desa

Masyarakat sipil menurut Culla ( 2006: 19) merupakan jaringan hubungan sosial yang dibangun orang per orang di antara mereka sendiri dalam konteks kelompok atau komunitas; hubungan tersebut lebih dilandaskan atas dasar timbal balik, 
egalitarianism inklusif dan kesukarelaan untuk menggalang solidaritas kemanusiaan, dan mewujudkan kebaikan bersama (public good) daripada atas dasar hukum kewajiban yuridis; peraturan dicipatkan sendiri untuk menata hubungan diantara mereka, sementara negara menggunakan 'aturan dari luar' yang menggunakan kekerasan dan paksaan ; keberadaan mereka tidak bergantung pada perantaraan otoritas lembaga negara. Mereka selalu berusaha membangun kreativitas serta berupaya mengatur dan memobilisasi diri sendiri secara otonom tanpa melibatkan negara. AS Hikam seperti dikutip Culla (2006:20) menjelaskan masyarakat sipil memiliki beberapa karakteristik seperti kesukarelaan (voluntary), keswadayaan (selfsupporting), keswasembadaan (self-generating), kemandirian (autonomy) tinggi saat berhadapan dengan negara dan memiliki keterikatan kuat dengan norma-norma atau nilai hukum yang disepakati. Culla (2006:21) menyimpulkan bahwa masyarakat sipil adalah yang mereka yang memiliki kemandirian yang membuat mereka mampu memajukan diri sendiri, bisa menghalangi intervensi pemerintah dan negara dalam realitas yang diciptakan sendiri, serta mampu menunjukkan sikap kritis di bidang kehidupan politik.

Berada di luar struktur pemerintahan desa ditambah dengan dicabutnya kewenangan legislasinya, BPD memang dirancang untuk memperkuat peran representasi dan pengawasan masyarakat terhadap pemerintahan desa. Dipilih secara demokratis dari perwakilan warga masyarakat, anggota BPD lebih tepat diposisikan sebagai representasi kepentingan masyarakat yang harus menjadi melakukan komunikasi politik intensif dengan konstituen mereka dalam rangka artikulasi, agregasi dan deliberasi permasalahan publik untuk selanjutnya didesakkan sebagai rancangan kebijakan publik. Peran dan fungi pengawasannya akibat kedudukan kelembagaannya yang berada di luar struktur pemerintahan desa, kian menegaskan posisi BPD sebagai unsur masyarakat sipil. Posisinya sebagai aktor strategis masyarakat sipil kian nampak nyata saat menghelat kegiatan Musyawarah Desa yang memungkinkannya untuk dapat meningkatkan posisi tawar politik warga terhadap pemerintahan desa terutama saat penyampaian laporan kinerja penyelenggaraan pemerintahan desa. Melalui "panggung"perhelatan Musyawarah Desa yang merupakan forum penting karena dihadiri elit desa seperti kepala desa, lembaga kemasyarakatan dan unsur masyarakat, BPD seharusnya dapat menjadikannya sebagai arena untuk mengoptimalkan peran representasi, agregasi kepentingan politik warga, delibarasi serta menggairahkan partisipasi. Berada di luar struktur pemerintahan desa tapi tetap dituntut untuk melakukan fungsi pemerintahan, lembaga ini dapat diasumsikan sebagai unsur masyarakat sipil desa. Sebagai bagian dari warga masyarakat, ia dapat melakukan perubahan dan menciptakan sejarah dengan cara melakukan agregasi berbagai kepentingan dengan mentransformasikan kepentingankepentingan sempit menjadi pandangan yang lebih universal sebagai ideologi lantas membentuk aliansi dengan semua pemegang 
kepentingan untuk mewujudkan ideologi tersebut (Mansour Fakih: 1996: 60). Bertindak sebagai kekuatan masyarakat sipil, BPD harus mampu memperjuangkan kepentingan warga dengan menghindari sejauh mungkin relasirelasi kolutif manipulatif dengan pemerintah desa. Sebagai pengawas kinerja pemerintahan desa, BPD hendaknya meletakkan aspirasi dan kepentingan masyarakat sebagai prioritas utama saat menjalankan tugas dan perannya. Ini mengingat legitimasi anggota BPD dibangun atas dasar kepercayaan warga masyarakat untuk dapat memaksimalkan fungsi pengawasan kinerja pemerintahan desa. Lewat optimalnya pengawasan BPD, nilai-nilai transparansi, akuntabilitas, partisipasi akan secara perlahan melembaga dalam tata kelola penyelenggaraan pemerintahan desa. Dengan setting seperti ini, akan terbangun mekanisme demokrasi desa yang disandarkan atas nilai -nilai transparansi, akuntabel, partisipatif tetapi tetap menjalankan prinsip-prinsip komunitarian seperti gotong royong, kebersamaan (keguyuban), dan musyawarah mufakat. Demokrasi di sini menurut Sutoro Eko et.al (2015:4) menjadi asas, nilai, sistem dan tata kelola sehingga melahirkan demokrasi yang inklusif, deliberatif dan partisipatif yang menempatkan semua pemegang kepentingan pada posisi setara. inilah demokrasi yang mengusung semangat: "demokrasi untuk setiap orang, bukan hanya untuk mayoritas" Sutoro Eko et.al (2015:55). Nah agar dapat terbangun tata kelola demokrasi seperti, BPD dapat melakukan advokasi hak warga atas informasi sebagai sebuah ikhtiar politik untuk melembagakan tata kelola demokrasi ini.

\section{Hak Masyarakat Atas Informasi Publik}

Informasi secara etimologis berasal dari kata Latin informare yang berarti memberikan bentuk atau membentuk sebuah gagasan. Hak atas informasi, makanya menjadi kebutuhan pokok setiap manusia untuk mewujudkan segenap potensi sosial, politik dan ekonomi setiap individu. Ini menyangkut beragam pengetahuan tentang berbagai isu yang melibatkan beragam pemegang kepentingan mulai dari pasar hingga pemerintahan yang memungkinan setiap individu agar dapat mengambil keputusan. Ini juga merupakan sumber daya publik yang harus ditata dan disimpan serta disebarluaskan oleh lembaga pemerintahan dalam rangka meningkatkan kepercayaan warga masyarakat. Hal ini karena setiap warga yang memiliki kesadaran politik ingin berperan dalam mempengaruhi dan mengarahkan permasalahan publik mereka. Dengan demikian, lewat semangat publik ini, individu dapat mengaktualisasikan identitasnya dan menyadari bahwa ia harus memberikan sumbangan terhadap kesejahteraan sosial (Malik: 2013:43).

Hak warga atas informasi yang mewujud dalam bentuk transparansi menurut Harrison, T.M., \& Sayogo, D.S (2014;1) adalah sebuah kondisi yang memungkinkan warga memperoleh akses terhadap data dan dokumen yang menyangkut perilaku dan tindakan yang dilakukan penyelenggara pemerintahan. Informasi seperti ini berperan penting bagi warga untuk dapat memonitor dan mendeteksi perilaku korup para 
penyelenggara pemerintahan serta mendesak mereka untuk bertindak akuntabel. Hal ini sebagai konsekwensi dari prinsip demokrasi representatif yang mengasumsikan bahwa legitimasi dibangun atas dasar kepercayaan warga (people's trust) ; bahwa pemimpin yang terpilih berupaya untuk memenuhi keingingan masyarakat. Nah kepercayaan masyarakat seperti ini harus dikembangkan dan dirawat melalui sebuah relasi kompleks antara transparansi, akuntabilitas dan partisipasi. Singkat kata, informasi merupakan jantung bagi berlangsungnya mekanisme demokrasi. Informasi merupakan oksigen yang menghidupkan kinerja demokrasi. Kalau warga masyarakat tidak mengetahui apa yang terjadi di lingkungan mereka, atau informasi tentang perilaku penyelenggara pemerintahan tersembunyi, tidak dipublikasikan secara meluas, mereka tidak akan mampu berkontribusi secara positif dalam dikusi permasalahan publik. Tidak hanya kebutuhan pokok hidup, informasi publik juga merupakan bagian penting integral bagi pemerintahan yang baik. Informasi publik memungkinkan masyarakat untuk mengawasi perilaku penyelenggara pemerintahan. Ini merupakan bahan baku perdebatan publik untuk membahas permasalahan publik (Toby Mendel : 1999:1). Dari dapat disimpulkan bahwa transparansi dan akuntabilitas merupakan kunci utama dalam menuntaskan gagalnya proses pembangunan dan buruknya implementasi demokrasi. Penerapan kedua prinsip menurut McGee, Rosie. Gaventa, John ( 2011: 6-7) akan mencegah tindakan korupsi dan mampu memperbaiki inefisiensi layanan publik. Ini $\begin{array}{lcr}\text { merupakan cara } & \begin{array}{c}\text { efektif } \\ \text { memberdayakan }\end{array} & \text { untuk } \\ \text { masyarakat } & \text { dan }\end{array}$ meningkatkan kemampuan penyedia layanan publik dalam menyerap kebutuhan dan aspirasi masyarakatmenurut McGee, Rosie. Gaventa, John ( 2011: 6-7).

Singkat kata, informasi publik merupakan kekuatan masyarakat yang mendorong mereka untuk dapat terlibat aktif dalam permasalahan bersama sehingga memungkinkan mereka untuk berpartisipasi dalam proses pengambilan keputusan publik. Hal ini berarti menggambarkan pentingnya pemerintahan yang terbuka (open government) yang mewajibkannya untuk memberikan layanan informasi publik kepada masyarakat sehingga mereka dapat berpartisipasi dalam mengambil keputusan dan kebijakan publik. Tidak heran kalau bapak konstitusi Amerika James Madison tahun 1822 mengatakan,

"a popular government without popular information or the means of acquiring it, is but a prologue to a farce or a tragedy or perhaps both. Knowledge will forever govern ignorance, and people who mean to be their own governors, must arm themselves with the power which knowledge gives."

Perundangan yang mengatur jaminan hak warga atas informasi publik adalah UU No 14 Tahun 2014 Tentang Keterbukaan Informasi Publik. Informasi publik menurut UU ini adalah informasi yang dihasilkan, disimpan, dikelola, dikirim, dan/atau diterima oleh suatu badan publik yang berkaitan dengan penyelenggara dan penyelenggaraan negara dan/atau 
penyelenggara dan penyelenggaraan badan publik lainnya yang sesuai dengan UndangUndang ini serta informasi lain yang berkaitan dengan kepentingan publik.Karena menjadi badan publik akibat operasionalnya didanai dari dana publik (APBN/APBD), pemerintah desa wajib menyediakan layanan keterbukaan informasi publik yang menurut UU ini terutama Pasal 3 dimaksudkan untuk ; (a) menjamin hak warga negara untuk mengetahui rencana pembuatan kebijakan publik, program kebijakan publik, dan proses pengambilan keputusan publik, serta alasan pengambilan suatu keputusan publik; (b) mendorong partisipasi masyarakat dalam proses pengambilan kebijakan publik; (c) meningkatkan peran aktif masyarakat dalam pengambilan kebijakan publik dan pengelolaan Badan Publik yang baik; (d) mewujudkan penyelenggaraan negara yang baik, yaitu yang transparan, efektif dan efisien, akuntabel serta dapat dipertanggungjawabkan; (e) mengetahui alasan kebijakan publik yang mempengaruhi hajat hidup orang banyak; mengembangkan ilmu pengetahuan dan mencerdaskan kehidupan bangsa; (g) meningkatkan pengelolaan dan pelayanan informasi di lingkungan Badan Publik untuk menghasilkan layanan informasi yang berkualitas. Layanan keterbukaan informasi publik, makanya menjadi kewajiban pemerintahan desa seperti ditegaskan pada pasal 13 dengan cara (1) menunjuk Pejabat Pengelola Informasi dan Dokumentasi (PPID) ; (2) membuat dan mengembangkan sistem penyediaan layanan informasi secara cepat, mudah, dan wajar. Di samping itu, badan publik seperti dinyatakan pada pasal 7 wajib ; (1) wajib menyediakan, memberikan dan/atau menerbitkan Informasi Publik yang berada di bawah kewenangannya kepada Pemohon Informasi Publik; (2) menyediakan Informasi Publik yang akurat, benar, dan tidak menyesatkan. Hal ini karena informasi publik menjadi hak setiap warga seperti dinyatakan pada pasal 4 ayat 2 bahwa setiap orang berhak: (a)melihat dan mengetahui Informasi Publik; (b) menghadiri pertemuan publik yang terbuka untuk umum untuk memperoleh Informasi Publik; (c) mendapatkan salinan Informasi Publik melalui permohonan; (d) menyebarluaskan Informasi Publik sesuai dengan peraturan perundang-undangan. Kewajiban menerapkan UU ini sekaligus sebagai jawaban atas minimnya tata kelola informasi yang baik pada UU Desa beserta aturan perundangan turunannya.

Keterbukaan informasi publik ini belum terakomodasi sepenuhnya dalam UU Desa yang hanya menyebutnya 5 kali sedangkan 9 lainnya lebih berkaitan dengan Sistem Informasi Desa. Hak warga atas informasi publik ini disebut pada pasal 27 tentang kewajiban kepala desa point d yang menyatakan memberikan dan/atau menyebarkan informasi penyelenggaraan pemerintahan secara tertulis kepada masyarakat Desa setiap akhir tahun anggaran. Kemudian pada pasal 68 tentang hak masyarakat desa untuk meminta dan mendapatkan informasi dari Pemerintah Desa serta mengawasi kegiatanpenyelenggaraan Pemerintahan Desa, pelaksanaan Pembangunan Desa, pembinaan 
kemasyarakatan Desa, dan pemberdayaan masyarakat Desa. Lantas pada pasal 82 tentang Pemantauan dan Pengawasan Pembangunan Desa yang menyatakan bahwa (1) Masyarakat Desa berhak mendapatkan informasi mengenai rencana dan pelaksanaan Pembangunan Desa; (4) Pemerintah Desa wajib menginformasikan perencanaan dan pelaksanaan Rencana Pembangunan Jangka Menengah Desa, Rencana Kerja Pemerintah Desa, dan Anggaran Pendapatan dan Belanja Desa kepada masyarakat Desa melalui layanan informasi kepada umum dan melaporkannya dalam Musyawarah Desa paling sedikit 1 (satu) tahun sekali. Hal yang sama juga ditemukan pada aturan turunannya baik Peraturan Pemerintah maupun Peraturan Menteri terkait. PP No 43 tentang Peraturan Pelaksanaan UndangUndang Nomor 6 Tahun 2014 Tentang Desa menyebut satu kali, yakni pada pasal 52 yang menyatakan Kepala Desa menginformasikan secara tertulis dan dengan media informasi yang mudah diakses oleh masyarakat mengenai penyelenggaraan Pemerintahan Desa kepada masyarakat Desa. Demikian juga halnya dengan Peraturan Menteri terkait. Peraturan Menteri Desa, Pembangunan Daerah Tertinggal, Dan Transmigrasi Nomor 1 Tahun 2015 Tentang Pedoman Kewenangan Berdasarkan Hak Asal Usul Dan Kewenangan Lokal Berskala Desa hanya menyebut satu kali pada Pasal 8 tentang Kewenangan lokal berskala Desa di bidang pemerintahan Desa yakni tentang pengembangan sistem administrasi dan informasi Desa. Meski demikian, hak informasi masyarakat ini mendapatkan jaminan yang muncukupi yang menyebutkan secara eksplisit hak tersebut sebanyak 20 kali. Hal ini terdapat pada Peraturan Menteri Desa, Pembangunan Daerah Tertinggal, Dan Transmigrasi Republik Indonesia Nomor 2 Tahun 2015 Tentang Pedoman Tata Tertib Dan Mekanisme Pengambilan Keputusan Musyawarah Desa. Singkat kata, upaya menerapkan keterbukaan informasi publik dalam tata kelola pemerintahan desa belum menjadi prioritas utama bagi Kementerian Desa. Ini dapat dilihat dari penetapan indikator Indeks Desa Membangun yang tidak memasukkkan kriteria layanan informasi publik sebagai indikator utama seperti yang tercantum dalam Peraturan Menteri Desa, Pembangunan Daerah Tertinggal, Dan Transmigrasi Republik Indonesia Nomor 2 Tahun 2016 Tentang Indeks Desa Membangun yang menilai dari aspek ketahanan sosial, ekonomi dan ekologi desa. Indikator layanan publik pemerintahaan desa, terutama aspek layanan informasi publik tidak disebutkan. Padahal aspek layanan publik ini sangat strategis yang sejalan dengan amanat UU No 25 Tahun 2009 Tentang Layanan Publik dan UU No 14 tahun 2008 tentang Keterbukaan Informasi publik.

\section{Penerapan Layanan Informasi Publik}

Hak warga atas informasi publik belum sepenuhnya diterapkan secara penuh. Ini yang dipaparkan Fasihol (2010; 33-42)) yang menemukan adanya ketertutupan bahkan kerahasiaan dalam mengakses informasi publik oleh masyarakat. Penelitian yang dilakukan di propinsi Nusa Tenggara Timur ini juga mendapatkan buruknya standard 
layanan informasi publik akibat dari belum dibentuknya PPID. Ini kemudian diperparah dengan minimnya kesadaran pejabat dan masyarakat akan hak atas informasi. Buruknya layanan informasi publik dan minimnya kesadaran masyarakat terhadap pentingnya informasi publik sama sebangun dengan lemahnya pengawasan masyarakat terhadap kinerja lembaga publik. Hal ini berpotensi terhadap penyelewengan kewenangan dan tindak pidana korupsi. KPK dalam laporannya tahun 2015 menemukan tidak optimalnya saluran pengaduan masyarakat untuk melaporkan kinerja perangkat desa yang mal-administrasi. Untuk itu, lembaga anti suap ini merekomendasikan pemerintah untuk merevisi Permendagri No. 07 tahun 2008 tentang Pengawasan atas Penyelenggaraan Pemerintahan Desa, dengan memasukan aspek pengawasan partisipatif oleh masyarakat, audit sosial, mekanisme pengaduan. Revisi PP 43/2014 dengan memasukkan kewajiban kepala desa mempublikasikan RAPBDesa untuk diriview oleh masyarakat dan menyediakan saluran keluhan/umpan balik masyarakat atas RAPBDesa juga diperlukan dalam rangka mencegah potensi korupsi pemerintah desa.

\section{Advokasi Hak Informasi Publik Sebagai Upaya Pemberdayaan Masyarakat}

Advokasi dapat diartikan secara sederhana sebagai proses berbicara atas nama orang lain. Makna ini berkembang mencakup tindakan yang dilakukan oleh agen pembangunan, masyarakat sipil untuk melakukan perubahan. Secara istilah berarti proses mengelola informasi dan pengetahuan secara strategis untuk mempengaruhi atau mengubah perilaku atau kebijakan yang berdampak pada kehidupan masyarakat terutama kaum pinggiran. Jadi tujuan utama advokasi adalah melakukan perubahan dari berbagai aspek seperti sikap dan perilaku politik, proses pengambilan keputusan Aspek penting dalam kegiatan advokasi adalah pelibatan warga masyarakat dalam melakukan perubahan. Advokasi makanya tidak hanya berkaitan dengan merancang perubahan dalam bidang kebijakan dan program tapi juga mencakup membangun kapasitas, tata kelola sumber daya kekuasaan masyarakat sipil serta pelibatan mereka dalam proses pembuatan kebijakan (dimensi masyarakat sipil), meningkatkan legitimasi partisipasi masyarakat sipil serta mengembangkan akuntabilitas lembaga publik (dimensi ruang publik), meningkatkan kondisi material warga miskin serta memperluas kesadaran diri masyarakat sebagai warga yang memiliki hak dan kewajiban (dimensi keuntungan individu) Cathy Watson (2001:1-2) .

Agar upaya pemberdayaan tersebut dapat terlaksana, aspek tata kelola kegiatan tersebut perlu mendapatkan perhatian. Yang dimaksud dengan aspek tata laksana organisasi (organisational aspects) pemberdayaan masyarakat menurut Laverack (2001: 135-138) mencakup sebuah keterkaitan antara elemen inter personal seperti kendali individu, modal sosial, kohesivitas komunitas dan elemen-elemen kontekstual seperti kondisi politik, ekonomi dan sosial budaya. Aspek- aspek ini menggambarkan proses pemberdayaan masyarakat yang 
memungkinkan individu dan kelompok untuk mengelola diri mereka dan memobilisasi sumber daya yang dimiliki untuk melakukan perubagan sosial politik. Untuk itu diperlukan kepimpinan fungsional yang didukung oleh struktur organisasi yang mapan serta partisipasi warga komunitas. Ini karena kepemimpinan dan partisipasi warga saling terkait satu dengan yang lain. Partisipasi warga tanpa kepemimpinan formal yang kuat yang bertanggungjawab untuk menyelesaikan permasalahan serta memberikan arah akan mengakibatkan kegagalan proses pemberdayaan masyarakat. Nah proses seleksi pemimpin ini biasanya lebih ditentukan oleh norma sosial masyarakat.

Dari paparan di atas dapat ditegaskan bahwa BPD menjadi permain utama percaturan tata kelola pemerintahan dan demokrasi desa. Ini mengingat kedudukan politik strategisnya sebagai unsur masyarakat yang meniscayakannya untuk selalu mandiri memperjuangkan kepentingan warga masyarakat serta menjaga jarak dari intervensi kepentingan politik pemerintah desa. Memang di bidang legislasi desa, BPD sudah tidak berwenang lagi. Sebagai gantinya peran politik BPD diperkokoh melalui perluasan kewenangan pengawasannya. Musyawarah Desa yang merupakan forum kolektif asosiatif yang dihadiri para elit desa dijadikan sebagai panggung politik BPD untuk memainkan peran utama tersebut. karena fungsi dan kewenangan politiknya diperkuat, BPD makanya menjadi masyarakat sipil yang berperan sebagai kekuatan penyeimbang terhadap dominasi elit politik dan pencegah potensi godaan kooptasi pemerintahan desa. Nilai-nilai seperti transparansi, akuntabilitas, dan partisipasi dapat secara perlahan dapat diinstitusionaliasi dalam kehidupan demokrasi desa. Demokrasi inklusif yang diarahkan untuk merangkul secara mutualistik semua pemegang kepentingan desa. Untuk mencapai hal tersebut, BPD harus menjalin komunikasi politik dengan mereka berkaitan dengan alokasi sumber daya publik. Di samping itu, peran komunikator publik juga harus diperankan untuk hal tersebut. Komunikasi publik menurut Ahy H (2012:17, 27) merupakan proses komunikatif yang diarahkan untuk membentuk, mempengaruhi keputusan berkaitan dengan kebaikan bersama (common good) yang akan bermuara pada pengembangan serta revitaliasi tatanan sosial (social order). Ini terkait erat dengan ruang publik (public sphere); sebuah ruang yang steril dari kepentingan politik penguasa serta kepentingan ekonomi pengusaha. Dengan kata lain, ini merupakan proses komunikatif yang bertujuan untuk membentuk keputusan kolektif yang menyangkut kebaikan bersama. Ini mengindikasikan bahwa keputusan (politik dan moral) yang dihasilkan merupakan hasil kerja kolektif dan bahwa keabsahan sebuah keputusan tidak ditentukan oleh isi tapi melalui proses yang tepat. Hak warga atas informasi publik merupakan jantung demokrasi desa yang dibangun atas nilai transparansi dan akuntabilitas. Kalau demokrasi desa yang inklusif hendak dikembangkan, maka adalah tugas BPD untuk mengadvokasi warga terhadap pentingnya tata kelola pemerintahan desa yang berbasis 
pada layanan informasi publik seperti ditegaskan pada UU No 14 Tahun 2008. Ini selanjutnya akan bermuara pada pembentukan Pejabat Pengelola Informasi dan Dokumentasi (PPID) yang secara structural melekat pada sekretaris desa. Pengembangan struktur ini sama sebangun dengan penguatan pengawasan masyarakat terhadap kinerja pemerintahan sehingga dapat mencegah tindakan penyelewengan kewenangan dan tindak pidana korupsi. Ini mengindikasikan keberadaan pemerintahan terbuka (open government) yang memungkinkan warga untuk mengawasi dan berpartisipasi dalam pembuatan keputusan publik. Ini sekaligus juga menggambarkan sebuah tata kelola pemerintahan desa yang baik (good village governance). Gambaran utuh tentang hal ini dapat dilihat dalam diagram grafis di bawah ini.

\section{Gambar 1 :}

Model Penguatan Peran Pengawasan BPD lewat Advokasi Hak Informasi Publik Masyarakat

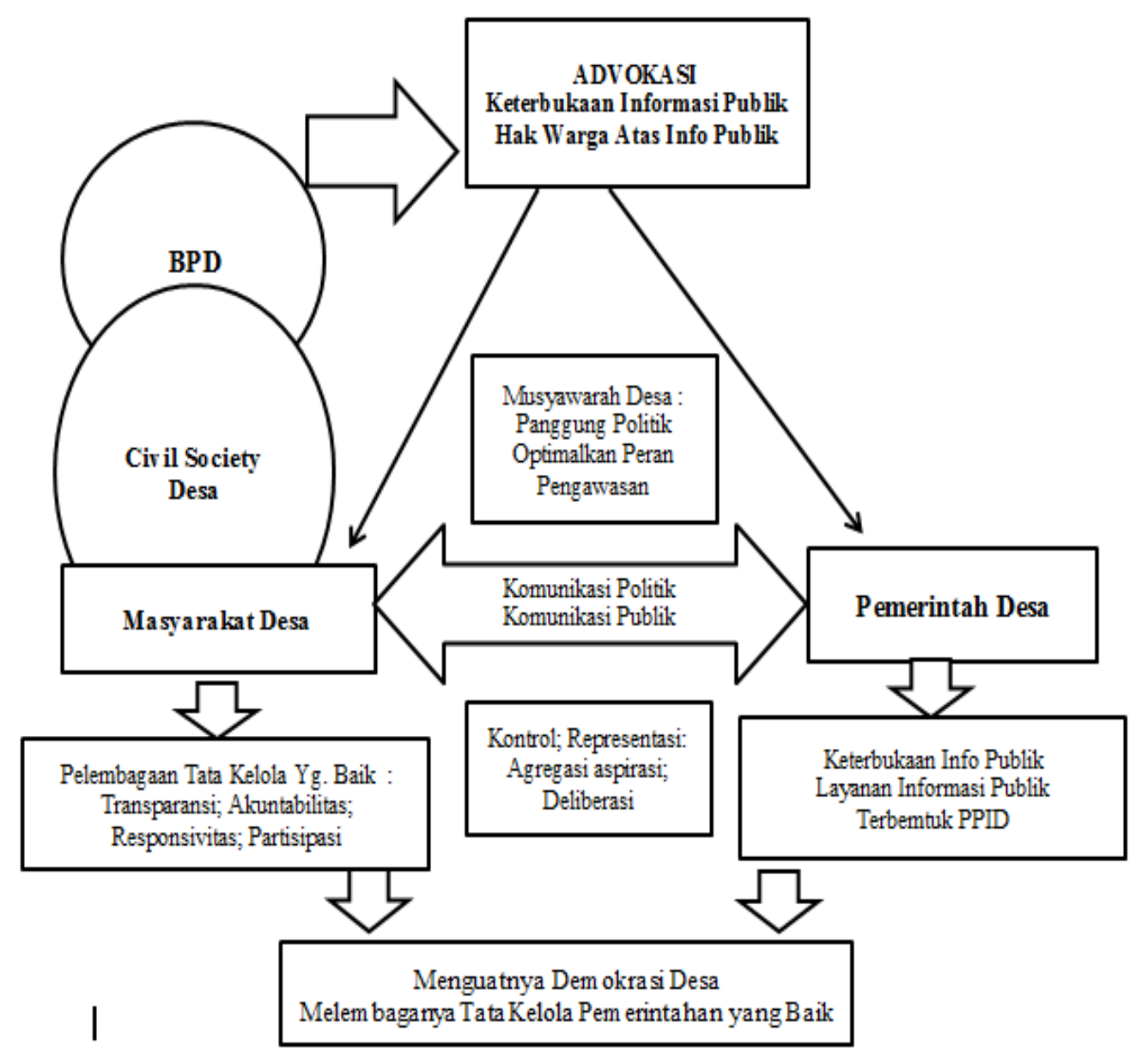

Volume 2, Nomor 1, April 2017

PUBLISIA (Jurnal Ilmu Administrasi Publik) | 67 


\section{KESIMPULAN}

Dari pembahasan di atas dapat disimpulkan bahwa: (1) BPD menjadi pemain kunci (key player) yang bertugas merancang dan memainkan peran strategis dalam menngembangkan tata kelola demokrasi desainklusif. Disebut demikian mengingat peran dan fungsi politik BPD terutama dalam hal pengawasan telah diperkuat melalui didudukannya lembaga ini di luar struktur organisasi pemerintahan desa. Ini sebagai subsitusi dari dihapuskannya peran legislasinya. Dengan setting seperti ini, anggota BPD lebih tepat mewakili unsur masyarakat sipil yang harus membeli kepentingan warga dengan mencegah campur tangan pemerintah dengan menghindari relasi kolutif manipulatif ; (2) Peran politik strategis BPD akan tercermin pada perhelatan Musyawarah Desa yang merupakan panggung politiknya. Kemampuan dalam mengelola forum kolektif asosiatif yang dihadiri elit desa ini mengharuskan untuk piawai dalam berkomunikasi politik dan publik sekaligus : (3) Agar demokrasi dapat berjalan mulus, nilai transparansi dan akuntabilitas perlu dilembagakan. Salah satunya adalah advokasi hak informasi publik yang dilakukan oleh BPD sebagai kekuatan masyarakat sipil yang hendaknya menjadi kekuatan penyeimbang politik terhadap pemerintahan desa.

\section{DAFTAR PUSTAKA}

Ahy, Hänska, Maximillian T., 2012, Public Communication as Ideal and Practice : Definition of the Common Good in Persian $\square$ anguage Transnational Newswork, A thesis submitted to the
Department of Media \& Communications of the London School of Economics for the degree of Doctor of Philosophy, London, diakses pada http://etheses.lse.ac.uk/627/1/HänskaAhy_Public_Communication_Ideal.pdf Antlöv, Hans., Wetterberg, Anna \&Dharmawan, Leni (2016): Village Governance, Community Life, and the 2014 Village Law in Indonesia, Bulletin of Indonesian Economic Studies, diakses pada

http://dx.doi.org/10.1080/00074918.201 5.1129047

Culla, Suryadi, Adi, 2006, Rekonstruksi Civil Society: Wacana dan Aksi Ornop di Indonesia, LP3ES, Jakarta

Eko, Sutoro, 2015, Regulasi Baru, Desa Baru; Ide, Misi, dan Semangat UU Desa, Kementerian Desa, Pembangunan Daerah Tertinggal, dan Transmigrasi Republik Indonesia, Jakarta

............, et.al, 2014, Desa Membangun Indonesia, Forum Pengembangan Pembaharuan Desa (FPPD), Yogyakarta.

Eko, Sutoro, et.al., 2015, Modul Pelatihan Penyegaran; Buku 2 Lembar Informasi Pendampingan Desa: Pengakhiran PNPM Mandiri Perdesaan dan Implementasi Undang Undang Nomor 6 Tahun 2014 Tentang Desa. Direktorat Jenderal Pembangunan dan Pemberdayaan Masyarakat Desa Kemendesa Kementerian Desa, Pembangunan Daerah Tertinggal dan Transmigrasi Republik Indonesia

Faisol, Ahmad, 2010, Laporan Penelitian Penilaian Awal Akses Informasi Publik di Provinsi Nusa Tenggara Timur, ARTICLE 19 dan Yayasan Tifa, Jakarta

Fakih, Mansour, 1996, Masyarakat Sipil Untuk Transformasi Sosial : Pergolakan Ideologi LSM Indonesia, Pustaka Pelajar, Yogyakarta

Harrison, T.M., \& Sayogo, D.S., 2014, 
Transparency, Participation, and Accountability Practices in Open Government: A Comparative Study, Government Information Quarterly (2014), diakses pada http://dx.doi.org/10.1016/j.giq.2014.08. $\underline{002}$

Kusumaputra, Ardhiwinda., Prasetyo, Dwi, Ngesti, tidak ada tahun, Model Penguatan Kedudukan Badan Permusyawaratan Desa Dalam Struktur Pemerintahan Desa, diakses pada tanggal 17 Juli 2017 pada https://media.neliti.com/media/public ations/35439-ID-model-penguatankedudukan-badan-permusyawaratandesa-dalam-struktur-pemerintahan.pdf.

Laverack, Glenn. (2001) “An Identification And

Interpretation Of TheOrganizational Aspects Of Community Empowerment".

Community Development Journal.

Volume 36 Issue 2.1 April 200136 (2): 4052.Diakses pada

https://doi.org/10.1093/cdj/36.2.134

Malik, Varun., 2013, Right to Information in India: A Hallmark of Democracy, International Journal of Management and Social Sciences Research (IJMSSR) ISSN: 2319-4421, Volume 2, No. 2, February 2013, diakses pada tanggal 5 Agustus 2017 di www.irjcjournals.org/ijmssr/Feb2013/8. pdf

McNair, Brian, 2011, An Introduction to Political Communication, Routledge, London

McGee, Rosie. Gaventa, John. 2011, Shifting

Power? Assessing the Impact of

Transparency and Accountability Initiatives, Institute of Development Studies / IDS Working Paper 383, London, United Kingdom

Mendel, Toby, 1999, The Public's Right to Know : Principles on Freedom of Information Legislation, ARTICLE 19 Global Campaign for Free Expression, London. Diakses pada tanggal 20 Juli 2017 di https://www.article19.org/pdfs/standa rds/righttoknow.pdf.

Watson, Cathy, 2003, Advocacy Sourcebook : A

Guide to Advocacy For WSSCC

Coordinators Working On The WASH

Campaign, Water Supply and Sanitation

Collaborative Council (WSSCC)

International Environment House,

Geneva, Switzerland

Deputi Bidang Pencegahan - KPK, 2015, Laporan Hasil Kajian Pengelolaan Keuangan Desa : Alokasi Dana Desa, Deputi Bidang Pencegahan - KPK, Jakarta.

\section{Peraturan dan Perundangan:}

Undang-Undang Republik Indonesia Nomor 14 Tahun 2008 Tentang Keterbukaan Informasi Publik

Undang- Undang Republik Indonesia Nomor 6 Tahun 2014 Tentang Desa

Undang- Undang Republik Indonesia Nomor 32 Tahun 2004 Tentang Pemerintahan Daerah

Undang- Undang Republik Indonesia Nomor 25 Tahun 2009 Tentang Layanan Publik

Peraturan Pemerintah Republik Indonesia Nomor 43 tahun 2014 Peraturan Pelaksanaan Undang Undang Nomor 6 Tahun 2014 Tentang Desa. 30 Mei 2014. Lembaran Negara Republik Indonesia Tahun 2014 Nomor 123. Jakarta.

Peraturan Pemerintah Republik Indonesia Nomor 47 Tahun 2015 Tentang Perubahan Atas Peraturan Pemerintah Nomor 43 Tahun 2014 Tentang Peraturan Pelaksanaan Undang-Undang Nomor 6 Tahun 2014 Tentang Desa, Jakarta

Peraturan Menteri Desa, Pembangunan Daerah Tertinggal, Dan Transmigrasi Republik Indonesia Nomor 1 Tahun 2015 Tentang Pedoman Kewenangan Berdasarkan Hak Asal Usul Dan 
Kewenangan Lokal Berskala Desa, Jakarta

Peraturan Menteri Desa, Pembangunan Daerah Tertinggal, Dan Transmigrasi Republik Indonesia Nomor 2 Tahun 2015 Tentang Pedoman Tata Tertib Dan Mekanisme Pengambilan Keputusan Musyawarah Desa, Jakarta

Peraturan Menteri Desa, Pembangunan Daerah Tertinggal, Dan Transmigrasi Republik Indonesia Nomor 2 Tahun 2016 Tentang Indeks Desa Membangun, Jakarta 